\title{
ЗАХИСТ РОСЛИН
}

УДК 633.63:632.7

\section{Шкідлива ентомофауна агроценозу буряків цукрових}

\author{
Ворожко С. П. , Грищенко О. М. \\ Інститут біоенергетичних культур і иукрових буряків НААН Украӥни, вул. Клінічна, 25, м. Київ, \\ 03110, Україна, "e-mail: svitlana.vorozhko@gmail.com
}

Мета. Уточнити видовий склад ентомофауни в екосистемі бурякового поля та виявити домінуючих шкідників у посівах культури за сучасної технології вирощування в умовах Правобережного Лісостепу України. Методи. Польовий, обліковий, статистичний, аналітичний. Результати. Уточнено видовий склад шкідливої ентомофауни агроценозу буряків цукрових в Правобережному Лісостепу України. За результатами досліджень у посівах цієї культура виявлено 30 видів шкідливих комах, які належать до 13 родин та 5 рядів. За період вегетації рослини буряків цукрових пошкоджувались комплексом фітофагів, які змінювали один вид іншим. Так, висіяне насіння і паростки буряків цукрових пошкоджували личинки коваликів та травневого хруща, гусениці озимої совки та крихітка бурякова; у фазі 1-2 пар листків культури - бурякові блішки, бурякові довгоносики звичайний і сірий, мідляк піщаний; у фазі 3-6 пар листків - попелиця листкова бурякова, цикадки і мухи бурякові мінувальні; у фазі змикання листків у рядках - клопи польовий i буряковий, блішки звичайна і бурякова, совка капустяна; з червня по вересень - совки листогризучі і підгризаючі. На основі результатів обліків членистоногих у посівах буряків цукрових було розраховане видове їх різноманіття. Встановлено, що показник різноманіття за індексом Менхініка становив 0,28-0,64,за індексом Бергера-Паркера максимально досягав 0,83 . Високий відсоток домінування за цим індексом пов'язаний із значним поширенням жуків блішки звичайної бурякової Chaetocnema concinna Marsh. Встановлено особливості формування ентомокомплексу у різні періоди розвитку культури. Вивчено динаміку чисельності домінантних видів шкідників та їх шкідливість. Висновки. В умовах Правобережного Лісостепу України на посівах буряків цукрових виявлено 30 видів шкідливих комах, що належать до 13 родин та 5 рядів. Високим видовим різноманіттям характеризувався ряд жуки (Coleoptera), частка представників якого становила 71,5 \% від загальної кількості виявлених фітофагів. Наступним був ряд рівнокрилі (Homoptera) 23,6 \%. Менш чисельними (3,1-0,7 \%) були представники рядів Hemiptera, Lepidoptera, Diptera. Встановлено, що кожний вид фітофага пристосований до певного етапу органогенезу рослин культури.

Ключові слова: домінуючі види, ентомокомплекс, індекси біорізноманіття, таксономічна належність.

\section{Вступ}

3 початку вирощування буряків цукрових почав формуватися і фауністичний комплекс шкідливої ентомофауни, низка видів комах якого, отримавши сприятливі умови для розвитку й масового розмноження, значно пошкоджували і навіть часто знищували посіви культури.

Агробіоценозам характерні особливості, що відрізняють їх від природних біоценозів. Рослинний покрив їх складається з одного або декількох видів культивованих рослин, яким супутні специфічні види шкідливих організмів. I хоч існування польових агробіоценозів в умовах сівозмін має короткочасний характер, але й цього періоду життя агроценозу достатньо, щоб склався певний фауністичний комплекс шкідливої фауни. 


\section{ЗАХUСТ РОСЛИН}

Сталість фауністичного комплексу в агробіоценозі, що зберігається в часі й просторі, має основні властивості будь-якого біоценозу і $є$ результатом природного відбору, що відбувався у даному місці в умовах, створених сільськогосподарською діяльністю людини за культивування того або іншого виду рослин із застосуванням тих або інших способів агротехніки і т.д. [1,2].

Дослідженнями багатьох вчених встановлено, що комахи є однією із найважливіших ланок у структурі агробіоценозу, оскільки об'єднують представників різних трофічних рівнів. Контроль за чисельністю фітофагів $\epsilon$ необхідною умовою отримання високих урожаїв, тому формуванню ентомокомплексу на посівах культурних рослин приділяється увага як науковців, так і практиків [3, 4].

Людина своєю діяльністю спричиняє зміни в природних екосистемах, що створюють у будь-якому біоценотичному комплексі умови, несприятливі для одних видів та сприятливі для інших. Як наслідок, між видами складаються нові співвідношення, перебудовуються трофічні ланцюги і виникають пристосування для існування у зміненому середовищі $[5,6]$.

Ентомофауна буряків цукрових налічує понад 200 видів шкідників, що належать до різних класів, рядів і родин. Але на теренах нашої держави їх кількість обмежується 30-40 видами, від яких щорічно доводиться захищати цю культуру $[2,3]$.

Мета досліджень - уточнити видовий склад ентомофауни в екосистемі бурякового поля та виявити домінуючих шкідників у посівах культури за сучасної технології iї вирощування в умовах Правобережного Лісостепу України.

\section{Матеріали та методика досліджень}

Дослідження проводили на Верхняцькій дослідно-селекційній станції Інституту біоенергетичних культур і цукрових буряків НААН (Черкаська обл.) упродовж 2012-2015 рр.

Грунт дослідних полів - чорнозем опідзолений важкого механічного складу, що характеризується такими агрохімічними показниками: вміст гумусу (за методом Тюріна) 3,36-4,89\%, гідролітична кислотність (за Каппеном) 2,2-3,8 ммоль на 100 г грунту, вміст рухомих форм фосфору і калію (за Чиріковим) - 90-140 і 70-100 мг/кг грунту відповідно, легкогідролізованого азоту (за Тюріним-Кононовою) 100-120 мг/кг грунту, сума увібраних основ (за Каппеном-Гільковіцем) в орному шарі - 28-30 ммоль на 100 г грунту. За градацією такий грунт має середню забезпеченість рослин азотом.

Серед погодних умов вирішальне значення мали тепло та вологозабезпечення. За кількістю та характером випадання опадів, територія проведення досліджень належить до зони нестійкого зволоження Правобережного Лісостепу України.

Видовий склад i чисельність фітофагів та ентомофагів встановлювали за загальноприйнятими та спеціальними методиками [7-9]. Грунтових шкідників обліковували за допомогою грунтових розкопок, зокрема чисельність крихітки бурякової пробовідбірником розміром $10 \times 10 \times 10 \mathrm{~cm}$, а наземних - спеціальною рамкою на облікових майданчиках розміром $1 \times 1\left(1 \mathrm{~m}^{2}\right)$ - екз./ $\mathrm{M}^{2}$, ентомологічним сачком (п.с. - помахів сачком), ящиком Петлюка, пастками Барбера.

Таксономічну належність комах встановлювали за допомогою визначників за участі спеціалістів Інституту зоології імені І. І. Шмальгаузена НАНУ [10-13].

\section{Результати досліджень}

У результаті моніторингу ентомоценозу в Правобережному Лісостепу України на посівах буряків цукрових виявлено 30 видів шкідливих комах, що належать до 13 родин та 5 рядів (рис. 1, табл. 1).

Встановлено, що найбільшим видовим різноманіттям характеризувався ряд жуки (Coleoptera), частка представників якого становила - 71,5\% від загальної кількості виявлених фітофагів. Наступним за кількістю комах був ряд рівнокрилі (Homoptera) - 23,6 \%, менш чисельними були інші представники рядів, кількість яких порівняно з всіма інших шкідниками становила $0,7-3,1$ \% відповідно. 


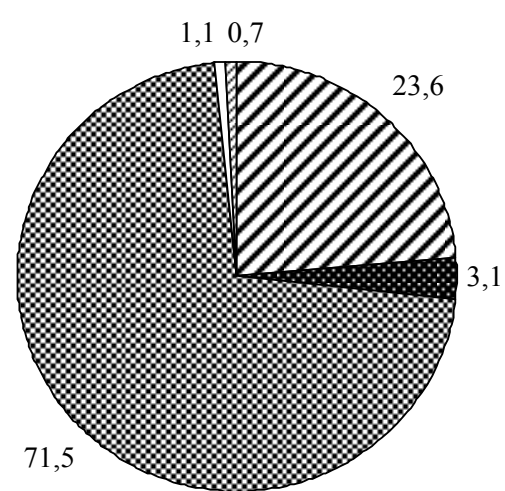

$\square$ Homoptera Hemiptera 0 Coleoptera $\square$ Lepidoptera $\square$ Diptera

Рис. Таксономічна структура шкідливого ентомокомплексу буряків цукрових (ВДСС, 2012-2015 рp.)

Таблиия 1

Видовий склад фітофагів у посівах буряків цукрових

(ВДСС, 2012-2015 рp.)

\begin{tabular}{|c|c|c|}
\hline Ряд & Родина & Вид \\
\hline \multirow{6}{*}{ Homoptera } & \multirow{3}{*}{ Cicadellidae } & Empoasca pteridis Dhlb. \\
\hline & & Eupteryx atropunctata Goeze. \\
\hline & & Kyboasca bipunctata Osh. \\
\hline & Cixiidae & Pentastiridius leporinus L. \\
\hline & \multirow{2}{*}{ Aphidinea } & Aphis fabae Scop. \\
\hline & & Pemphigus fuscicornis Koch. \\
\hline \multirow{4}{*}{ Hemiptera } & \multirow{4}{*}{ Miridae } & Lygus pratensis L. \\
\hline & & Orthotylus flavosparsus Sahlb. \\
\hline & & Polymerus cognatus Fieb. \\
\hline & & Polymerus vulneratus $\mathrm{Pz}$. \\
\hline \multirow{13}{*}{ Coleoptera } & \multirow{2}{*}{ Curculionidae } & Tanymecus palliatus $\mathrm{F}$. \\
\hline & & Asproparthenis punctiventris Germ. \\
\hline & \multirow{3}{*}{ Chrysomelidae } & Chaetocnema concinna Marsh. \\
\hline & & Chaetocnema breviuscula Fld. \\
\hline & & Cassida nobilis L. \\
\hline & \multirow{2}{*}{ Elateridae } & Agriotes sputator L. \\
\hline & & Selatosomus latus $\mathrm{F}$. \\
\hline & Cryptophagidae & Atomaria linearis Steph. \\
\hline & \multirow{2}{*}{ Scarabaeidae } & Onthophagus semicornis Ill. \\
\hline & & Melolontha melolontha L. \\
\hline & \multirow{2}{*}{ Silphidae } & Nicrophorus vespillo L. \\
\hline & & Thanatophilus sinuatus F. \\
\hline & Tenebrionidae & Opatrum sabulosum L. \\
\hline \multirow{4}{*}{ Lepidoptera } & \multirow{4}{*}{ Noctuidae } & Agrotis segetum Schiff. \\
\hline & & Xestia c-nigrum L. \\
\hline & & Autographa gamma L. \\
\hline & & Mamestra brassicae L. \\
\hline \multirow{2}{*}{ Diptera } & \multirow{2}{*}{ Anthomyiidae } & Delia platura $\mathrm{Mg}$. \\
\hline & & Pegomyia betae Curt. \\
\hline
\end{tabular}


Аналіз сукупної динаміки чисельності комах, спостереження за фенологією розвитку буряків цукрових дали змогу виявити групу фітофагів, супутніх певному етапу формування врожайності культури. За вегетаційний період посіви культури пошкоджувались комплексом шкідників, які змінюють один вид іншим.

Встановлено, що висіяне насіння та паростки буряків цукрових пошкоджують личинки коваликів (Agriotes sputator L.) - 9,8 екз./м² і травневого хруща (Melolontha melolonha L.) -

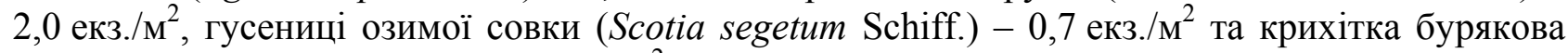
(Atomaria linearis Steph.) - 367,0 екз./ $\mathrm{m}^{2}$.

У фазі сходів у значній кількості зустрічалися блішки бурякові (Chaetocnema concinna Marsh. i Ch. breviuscula Fald.) - 14,0 екз./м², довгоносик звичайний буряковий (Asproparthenis punctiventris Germ.) - 0,8 екз./ м $^{2}$, довгоносик сірий буряковий (Tanymecus palliatus F.) 0,7 екз./м² і поодинокі особини мідляка піщаного Opatrum sabulosum L. - 0,2 екз./ $\mathrm{M}^{2}$.

У фазі 3-6 пар листків буряків у посівах спостережено зростання чисельності попелиці листкової бурякової Aphis fabae Scop. (190,0 екз./100 п.с.), цикадок Empoasca pteridis Dhlb. i Eupteryx atropunctata Goeze. (53,0 і 29,0 екз./100 п.с), мухи бурякової мінувальної Pegoтyia betae Curt. (4,0 лич./рослину).

Після змикання листків у рядках культури відловлювали клопів польового Lygus pratensis L. і бурякового Polymerus cognatus Fieb. (64,0 і 12,0 екз./100 п.c), блішки звичайної Chaetocnema concinna Marsh. і бурякової Ch. breviuscula Fld. (59,0 i 11,0 екз./м²), совки капустяної Mamestra brassicae L. - 3,0 екз./м².

3 червня по вересень спостерігали фітофагів з ряду лускокрилі: совки листогризучі C-чорне Xestia c-nigrum L. (3,0 екз./росл.), гамма Autographa gamma L. (5,0 особ./росл.), совки підгризаючі Agrotis segetum Schiff. (2,0 екз./ $\left.\mathrm{M}^{2}\right)$.

На основі результатів обліків членистоногих у посівах буряків цукрових було розраховане видове їх різноманіття, використовуючи індекси Менхініка і Бергера-Паркера (табл. 2).

Таблиия 2

Індекси біорізноманіття фітофагів у посівах буряків цукрових (ВДСС, 2012-2015 pp.)

\begin{tabular}{|l|c|c|}
\hline \multirow{2}{*}{\multicolumn{1}{|c|}{ Ряд }} & \multicolumn{2}{|c|}{ Показники біорізноманіття фітофагів } \\
\cline { 2 - 3 } & $\begin{array}{c}\text { індекс різноманіття } \\
\text { Менхініка }\end{array}$ & $\begin{array}{c}\text { індекс домінування } \\
\text { Бергера-Паркера }\end{array}$ \\
\hline Homoptera - рівнокрилі & 0,28 & 0,52 \\
\hline Hemiptera - клопи & 0,64 & 0,53 \\
\hline Coleoptera - жуки & 0,37 & 0,83 \\
\hline Lepidoptera - лускокрилі & 0,64 & 0,45 \\
\hline Diptera - двокрилі & 0,50 & 0,63 \\
\hline
\end{tabular}

Як свідчать дані таблиці 2, індекс різноманіття за індексом Менхініка становив 0,280,64 , а за індексом Бергера-Паркера максимально сягав 0,83 . Високий відсоток домінування за цим індексом пов'язаний із значним поширенням жуків блішки звичайної бурякової Chaetocnema concinna Marsh.

Проведені дослідження дали змогу встановити, що формування видового складу шкідників на посівах буряків цукрових іде поступово протягом вегетації рослин. Структура видового складу на різних періодах розвитку рослин складається за рахунок видів, що мігрують з інших біотопів, видів, що зимують на полях, де розміщені посіви та полівольтних видів, більша частина життєвого циклу яких проходить в цьому ж ценозі.

\section{Висновки}

В умовах Правобережного Лісостепу України на посівах буряків цукрових виявлено 30 видів шкідливих комах, що належать до 13 родин та 5 рядів. Високим видовим різноманіттям 
характеризувався ряд жуки (Coleoptera), частка представників якого становила 71,5 \% від загальної кількості виявлених фітофагів. Наступним був ряд рівнокрилі (Homoptera) $23,6 \%$. Менш чисельними (3,1-0,7\%) були представники рядів Hemiptera, Lepidoptera, Diptera. Встановлено, що кожний вид фітофага пристосований до певного етапу органогенезу рослин культури.

\section{Використана література} $276 \mathrm{c}$.

1. Зверозомб-Зубовский Е. В. Вредители сахарной свеклы. Киев : Изд. АН УССР, 1956. $463 \mathrm{c}$.

2. Федоренко В. П. Ентомокомплекс на цукрових буряках. Київ : Аграрна наука, 1998.

3. Саблук В. Т. Шкідники сходів цукрових буряків. Київ : Світ, 2002. 182 с.

4. Медведев С. И. Основные закономерности формирования энтомофауны Украины под влиянием деятельности человека. Tруды XIII Международного энтомологического конгресса. Киев, 1971. Т. 1. С. 526-528.

5. Грищенко О. М. Поширення та шкідливість бурякових довгоносиків. Цукрові буряки. 2010. № 4. C. 15-17.

6. Саблук В. Т., Грищенко О. М., Смірних В. М. Саморегуляція населення комах в агроценозі буряків цукрових - проблема і шляхи ії вирішення. Цукрові буряки. 2017. № 3. C. $18-21$.

7. Омелюта В. П., Григорович І. В., Чабан В. С. та ін. Облік шкідників і хвороб сільськогосподарських культур / під заг. ред. В. П. Омелюти. Київ : Урожай, 1986. 296 с.

8. Саблук В. Т., Грищенко О. М. Методи виявлення і обліку шкідників та пошкодженості ними рослин цукрових буряків. Методики проведення досліджень у буряківниитві / за ред. М.В. Роїка та Н. Г. Гізбулліна. Київ : ФОП Корзун Д. Ю., 2014. C. $102-125$.

9. Саблук В. Т., Грищенко О. М., Запольська Н. М. та ін. Методика досліджень 3 ентомології і фітопатології у посівах цукрових буряків / за ред. В. Т. Саблука. Київ : ФОП Корзун Д. Ю., 2013. 52 с.

10. Определитель насекомых Европейской части СССР : в 5 т. Т. 2: Жесткокрылые и веерокрылые / под ред. Т. Я. Бей-Биенко. Москва ; Ленинград : Наука, 1965. 668 с.

11. Мамаев Б. М., Медведев Л. Н., Правдин Ф.Н. Определитель насекомых Европейской части СССР. Москва : Просвещение, 1976. 304 с.

12. Определитель вредных и полезных насекомых и клещей однолетних и многолетних трав и зернобобовых культур в СССР / Л. М. Копанева (сост.). Москва : Колос, 1983. 272 с.

13. Вредители сельскохозяйственных культур и лесных насаждений : в 3 т. Т. 1: Вредные нематоды, моллюски, членистоногие / под ред. В. П. Васильева. 2-е изд., пер. и доп. Киев : Урожай, 1987. 440 с.

\section{References}

1. Zverozomb-Zubovskiy, E. V. (1956). Vrediteli sakharnoy svekly [Pests of Sugar Beet]. Kiev: Izd. AN USSR. [in Russian]

2. Fedorenko, V.P. (1998). Entomokompleks na tsukrovykh buriakakh [Sugar beet entomocomplex]. Kyiv: Ahrarna nauka. [in Ukrainian]

3. Sabluk, V. T. (2002). Shkidnyky skhodiv tsukrovykh buriakiv [Pests of sprouts of sugar beet]. Kyiv: Svit. [in Ukrainian]

4. Medvedev, S. I. (1971). The main regularities of the formation of the entomofauna of Ukraine under the influence of human activity. Trudy XIII Mezhdunarodnogo entomologicheskogo kongressa [Proceedings of the $13^{\text {th }}$ International Entomological Congress]. (Vol. 1, pp. 526-528). Kiev: N.p. [in Russian]

5. Hryshchenko, O. M. (2010). Distribution and harmfulness of beet weevils. Tsukrovi buriaky [Sugar Beet], 4, 15-17. [in Ukrainian] 
6. Sabluk, V. T., Hryshchenko, O. M., \& Smirnykh, V. M. (2017). Self-regulation of insect population in sugar beet agrocenosis: the problem and ways of solving. Tsukrovi buriaky [Sugar Beet], 3, 18-21. [in Ukrainian]

7. Omeliuta, V. P., Hryhorovych, I. V., \& Chaban, V. S. (1986). Oblik shkidnykiv i hvorob silskogospodarskykh kultur [Accounting of pests and diseases of agricultural crops]. Omeluta, V. P. (Ed.). Kyiv: Urozhai. [in Ukrainian]

8. Sabluk, V. T., \& Hryshchenko, O. M. (2014). Methods for the identification and recording of pests and damage to them by sugar beet plants. In M. V. Roik, \& N. H. Hizbullin (Eds.), Metodyky provedennia doslidzhen u buriakivnytstvi [Methods of research in sugar beet growing] (pp. 102-125). Kyiv: FOP Korzun D. Yu. [in Ukrainian]

9. Sabluk, V. T., Gryshchenko, O. M., \& Zapolska, N. M. (2013). Metodyka doslidzhen z entomolohii $i$ fitopatolohii $u$ posivakh tsukrovykh buriakiv [The methodology of research on entomology and phytopathology in sugar beet crops]. V. T. Sabluk (Ed.). Kyiv: FOP Korzun D. Yu. [in Ukrainian]

10. Bey-Bienko, T. Ya. (Ed.). (1965). Opredelitel' nasekomykh Evropeyskoy chasti SSSR. T. 2: Zhestkokrylye $i$ veerokrylye [Reference book for insects of the European part of the USSR. Vol. 2: Coleopteras i Strepsipteras]. Moscow; Leningrad: Nauka. [in Russian]

11. Mamaev, B. M., Medvedev, L. N., \& Pravdin, F. N. (1976). Opredelitel' nasekomykh Evropeyskoy chasti SSSR [Reference book for insects of the European part of the USSR. Tutorial]. Moscow: Prosveshchenie. [in Russian]

12. Kopaneva, L. M. (Ed.). (1983). Opredelitel' vrednykh i poleznykh nasekomykh i kleshchey odnoletnikh i mnogoletnikh trav i zernobobovykh kul'tur $v$ SSSR [Reference book for harmful and useful insects and mites of annual and perennial grasses and leguminous crops in the USSR]. Moscow: Kolos. [in Russian]

13. Vasil'ev, V.P. (Ed.). (1987). Vrediteli sel'skokhozyaystvennykh kul'tur i lesnykh nasazhdeniy. T. 1: Vrednye nematody, mollyuski, chlenistonogie [Pests of the agricultural crops and forest plantations. Vol. 1: Harmful nematodes, mollusks, arthropods]. ( $2^{\text {nd }}$ ed., rev.). Kiev: Urozhay. [in Russian]

\section{УДК 633.63:632.7}

Ворожко С. П. , Грищенко О. Н. Вредная энтомофауна агроценоза сахарной свеклы // Наукові праці Інституту біоенергетичних культур і цукрових буряків : сб. науч. тр. Киев, 2017. Вып. 25. С. 108-114.

Институт биоэнергетических культур и сахарной свекль НААН Украины, ул. Клиническая, 25, 2. Киев,03110, Украина, "e-mail: svitlana.vorozhko@gmail.com

Цель. Уточнить видовой состав энтомофауны в экосистеме свекловичного поля и выявить доминирующих вредителей в посевах культуры при современной технологии выращивания в условиях Правобережной Лесостепи Украины. Методы. Полевой, статистический, аналитический. Результаты. Проведены исследования с уточнения видового состава вредной энтомофауны агроценоза сахарной свеклы в Правобережной Лесостепи Украины. По результатам исследований в посевах этой культуры выявлено 30 видов вредных насекомых, которые принадлежат к 13 семействам и 5 рядам. За период вегетации растения сахарной свеклы повреждались комплексом фитофагов, которые меняли один вид другим. Так, высеянные семена и проростки сахарной свеклы повреждали личинки щелкунов и майского хруща, гусеницы озимой совки и крошка свекловичная; в фазе 1-2 пар листьев культуры - свекловичные блошки, свекловичные долгоносики обыкновенный и серый, песчаный медляк; в фазе 3-6 пар листьев - тля листовая свекловичная, цыкадки и мухи свекловичные минирующие; в фазе смыкания листьев в рядках - клопы полевой и свекловичный, блошки обыкновенная и свекловичная, совка капустная; с июня по сентябрь совки листогрызущие и подгрызающие. На основании результатов учетов членистоногих в посевах сахарной свеклы было рассчитано видовое их биоразнообразие. Установлено, что разнообразие по индексу Менхиника составляет 0,28-0,64, а по индексу Бергера-Паркера 
максимально 0,83. Большой процент доминирования по этому индексу связан со значительным распространением жуков свекловичной обыкновенной блошки Chaetocnema concinna Marsh. Установлено особенности формирования энтомокомплекса в разные периоды развития культуры. Изучена динамика численности видов вредителей и их вредоносность. Выводы. В условиях Правобережной Лесостепи Украины в посевах сахарной свеклы выявлено 30 видов вредных насекомых, что принадлежат к 13 семействам и 5 рядам. Высоким видовым разнообразием характеризовался ряд жуки (Coleoptera), представители которого составляли 71,5 \% от общего количества выявленных фитофагов. Следующим был ряд равнокрылые (Homoptera) - 23,6 \%. Менее численными (3,1-0,7\%) были представители рядов Hemiptera, Lepidoptera, Diptera. Установлено, что каждый вид приспособлен к определенному этапу органогенеза растений культуры.

Ключевые слова: доминирующие виды, энтомокомплекс, индексы биоразнообразия, таксономическая принадлежность.

\section{UDC 633.63: 632.7}

Vorozhko S. P., \& Hryshchenko O. M. (2017). Harmful entomofauna of sugar beet agrocoenosis. Nauk. praci İnst. bioenerg. kul't. cukrov. burâkiv [Scientific Papers of the Institute of Bioenergy Crops and Sugar Beet], 25, 108-114. [in Ukrainian]

Institute of Bioenergy Crops and Sugar Beet, NAAS of Ukraine, 25 Klinichna Str., Kyiv, 03110, Ukraine, "e-mail: svitlana.vorozhko@gmail.com

Purpose. To specify the species composition of the entomofauna in the sugar beet ecosystem and to identify the dominant pests in the sowings grown by a modern technology under the conditions of the Right-Bank Forest-Steppe of Ukraine. Methods. Field, accounting, statistical, analytical. Results. A research to specify the species composition of the harmful entomofauna of sugar beet agrocoenosis in the Right-Bank Forest-Steppe of Ukraine has been carried out. Based on the records of arthropods in sugar beet crops, their varieties diversity was calculated. According to the research results, 30 types of harmful insects belonging to 13 families and 5 orders were identified. During the period of vegetation, sugar beet plants were damaged by a group of phytophagans, which changed one species to another. Thus, seeds and sprouts of sugar beet were damaged by larvae of grasshopper, may-bug, and a pygmy beetle. In the of 2-4 true leaf stage, the plants were damaged by beet flea beetle, beet beetles, and sellar beetle; in 6-12 true leaf stage by the aphids and beet miner; in the stage of closing the leaves in the rows by flea beetle, cabbage moth and hemipterans; from June to September by owlet moths. It was found that the Menhinick's richness index was $0.28-0.64$, while the Berger-Parker index was high 0.83 . The high percentage of dominance in this index is associated with a significant distribution of beet flea (Chaetocnema concinna Marsh). The peculiarities of the entomocomplex formation in different periods of the crop development were determined. The dynamics of the number of the dominant pest types and their harmfulness were investigated. Conclusions. Under the conditions of the Right-Bank Forest-Steppe Ukraine, 30 types of harmful insects were identified on sugar beet sowings belonging to 13 families and 5 orders. Coleoptera order was characterized by significant species diversity representing $71.5 \%$ of the total number of identified phytophagans. The next was Homoptera (23.6\%). Hemiptera, Lepidoptera, and Diptera together accounted for $3.1-0.7 \%$. It was found that each phytophag species are adapted to a certain stage of plant organogenesis.

Keywords: dominant species, entomocomplex, indices of biodiversity, taxonomic affiliation.

Надійшла / Received 12.09.2017

Погоджено до друку / Accepted 4.10.2017 